\title{
NET SPLANCHNIC GLUCOSE PRODUCTION IN NORMAL MAN AND IN VARIOUS DISEASE STATES ${ }^{1}$
}

\author{
BY J. D. MYERS \\ (From the Department of Medicine, Duke University School of Medicine, Durham, North \\ Carolina)
}

(Submitted for publication May 1, 1950; accepted, July 24, 1950)

The liver is generally recognized as the major, if not the sole source of glucose to the body in the postabsorptive state. Estimation of the amount of glucose produced by the liver has been difficult until recent years because of the problem of measuring hepatic blood flow and of obtaining the proper bloods for calculation of the arterialhepatic venous and arterial-portal venous glucose differences. Soskin and coworkers (1), however, did make estimates of the hepatic glucose balance in extensively operated dogs. The recent introduction of the procedure of catheterization of the hepatic veins of man (2) has allowed estimation of the hepatic blood flow $(3,4)$ and the collection of blood samples from those veins for the determination of the glucose difference between hepatic venous and arterial bloods. This technique has been used by Bondy $(5,6)$ and ourselves (7) in the study of hepatic carbohydrate balance in normal and diabetic subjects.

The product of the arterial-hepatic venous glucose difference and the hepatic blood flow provides the splanchnic glucose production. The splanchnic area as used in this paper constitutes the liver plus the various viscera drained by the portal vein. The splanchnic blood flow is equal to the total hepatic blood flow in the absence of significant portal venous collaterals. The hepatic glucose output, however, exceeds the splanchnic glucose output, as calculated from the hepatic blood flow and the arterial-hepatic venous glucose difference, since the liver must make up for whatever glucose is consumed by the various portal viscera. The net splanchnic glucose output is thus defined as the hepatic glucose output minus the glucose consumption of the organs drained by the portal vein. The liver itself may be utilizing

1 These studies were supported by Grants from the Life Insurance Medical Research Foundation, the Anna $H$. Hanes Fund of Duke University, and the Duke University Research Council. and producing glucose simultaneously. Thus the hepatic glucose output determined by these methods is, again, a net hepatic glucose production.

Given a constant arterial concentration of glucose in the absence of glycosuria, the hepatic glucose output must equal the non-hepatic (peripheral) glucose utilization. Thus the net splanchnic glucose production serves as an estimate of the peripheral glucose consumption. Soskin and coworkers (1) showed that in the dog a slow infusion of glucose of a magnitude to balance the hepatic glucose output abolished the latter. This procedure has been utilized by us in balance with the net splanchnic glucose production in an attempt to check on the accuracy of the determination of splanchnic glucose production by the blood flow method.

Since portal venous blood is not obtainable in intact man and since knowledge of the arterialportal venous glucose difference and portal venous blood flow is necessary to correct net splanchnic glucose output to hepatic glucose production, the latter has heretofore not been determined in man. The presence of large, readily accessible portal venous collaterals in three patients with cirrhosis of the liver has allowed us to estimate the true hepatic glucose production in these individuals. Others (8-11) have used such portal collateral veins for study of the absorption of glucose and other substances from the intestine but never, in conjunction with arterial and hepatic venous glucose determinations, to investigate hepatic glucose balance.

This report, then, deals with the hepatic arteriovenous glucose differences and the net splanchnic glucose productions in a series of control subjects and in groups of patients with Laennec's cirrhosis of the liver, treated diabetes mellitus, hyperthyroidism, and chranic cardiac failure. These data are correlated with the oxygen consumption in the splanchnic area and in the 
rest of the body. Included are the reports of seven subjects in whom the splanchnic glucose production was estimated by the slow infusion of glucose, and the data on the three subjects with hepatic cirrhosis in whom true hepatic glucose productions were calculated.

\section{METHODS}

The hepatic blood flows were estimated by the bromsulphalein method of Bradley (3). All flows are calculated from the average of at least four determinations of hepatic arteriovenous bromsulphalein difference at five to ten minute intervals. The validity of the bromsulphalein method for determining hepatic blood flow has recently been contested on the basis that there is significant extra-hepatic loss of the dye $(12,13)$. That there is no significant loss of bromsulphalein in man in the distribution of the inferior vena cava below the hepatic veins at the plasma concentration at which we work (usually 0.75 to $3 \mathrm{mg}$. per $100 \mathrm{ml}$.) is evidenced by the fact that in 20 determinations on eight subjects, the bromsulphalein concentration in inferior vena caval blood averaged $1.27 \pm 0.55 \mathrm{mg}$. per cent ${ }^{2}$ whereas the simultaneous concentration in arterial blood averaged $1.28 \pm 0.55 \mathrm{mg}$. per cent. Concentrations of bromsulphalein in blood from the superior vena cava are slightly in excess of simultaneous arterial concentrations, due to dye being added to the superior caval circulation via the infusion in an arm vein.

Sherlock and coworkers (14) have claimed recently that there is appreciable extra-hepatic loss of bromsulphalein when one utilizes plasma levels of less than $1 \mathrm{mg}$. per $100 \mathrm{ml}$. in the estimation of hepatic blood flow, thus yielding artefactually high levels of flow. As will be reported in detail in a future communication, our experience does not agree with Sherlock's. In 39 control subjects whose hepatic blood flows were estimated at bromsulphalein concentrations varying from 1.02 to 2.89 mg. per cent, the mean hepatic blood flow was $748 \pm$ $154 \mathrm{ml}$. per minute per sq. M. of body surface, whereas in 12 other control subjects, who were studied at bromsulphalein concentrations between 0.76 and $0.98 \mathrm{mg}$. per cent, the mean flow was $843 \pm 168 \mathrm{ml}$. The difference between the two means is not statistically significant $(0.1>p>0.05)$. Furthermore, inspection of Sherlock's data on hepatic blood flow in normal subjects at low plasma bromsulphalein levels, brings out that in many of the subjects the calculated flows were high because of an abnormally low hepatic extraction of the dye. Thus in these instances the abnormality resulting in the high flow lay either in the liver or in improper placement of the venous catheter rather than in extra-hepatic removal of bromsulphalein.

Furthermore, successive determinations of hepatic blood flow in our laboratory at plasma bromsulphalein concentrations progressing from $0.5 \mathrm{mg}$. per cent to as high as $6 \mathrm{mg}$. per cent in the same control subjects uni-

2 The \pm value is the standard deviation. formly gave essentially identical estimation of hepatic blood flow at all plasma levels. This is evidence against appreciable extra-hepatic loss of dye even at these quite high blood concentrations. Urinary loss usually comprised about 3 per cent of the total dose infused and may, therefore, be disregarded. Brauer and others (15) have shown recently in dogs that, whereas only 30 to 70 per cent of infused bromsulphalein could be recovered from the bile, by using $\mathrm{S}^{\text {ss }}$ tagged bromsulphalein nearly quantitative recovery of the $S^{2 s}$ could be accomplished from liver, blood, and bile. This last evidence is in support of the validity of the bromsulphalein method for liver flow for it is immaterial in this procedure whether the dye is excreted in the bile unchanged or whether it is altered or even destroyed by the liver, just so long as such alteration does not take place in extra-hepatic tissues.

We must conclude that, as physiological measurements go, the bromsulphalein method gives a valid estimate of hepatic blood flow, that is, within 20 per cent of the true value in the individual case and probably much closer to the true flow when a series of similar subjects is studied. Furthermore, the estimation of the hepatic blood flow in control subjects by a completely different method (4) gave results which agreed closely with the bromsulphalein procedure.

No subject with disease which is known to impair hepatic function, such as Laennec's cirrhosis, hyperthyroidism, or congestive heart failure, is included in this report unless the hepatic extraction percentage for bromsulphalein was at least 10 per cent. Under these circumstances, it is thought that the bromsulphalein technique gives reasonably reliable estimates of the blood flows of these diseased livers.

Blood glucose was determined by the method of Somogyi (16) as modified by Nelson (17). Samples were preserved with sodium fluoride but nevertheless care was taken that protein-free filtrates were prepared promptly so as to avoid glycolysis. Blood oxygen contents were determined by either the manometric method of Van Slyke and Neill (18) or the colorimetric procedure of Hickam and Frayser (19). Total oxygen consumptions were determined by the method of Haldane on samples of expired air collected in Douglas bags.

All subjects were studied in the post-absorptive state, usually after an overnight fast. No special effort was made to control the diet during the several days preceding the test; all patients, however, had been eating reasonably well of the standard ward diet or of the diet usually prescribed for their disease. Phenobarbital 90 mg. or sodium pentobarbital $100 \mathrm{mg}$. orally was the only premedication used. The entire procedure, including venous catheterization, was generally accomplished without significant discomfort. After an interval of 10 minutes or thereabout to allow the subject to approach the basal state as closely as possible, blood samples for bromsulphalein, glucose and oxygen were collected. As a rule, four arterial, four hepatic venous, and when available four portal collateral venous samples were collected over a period of 20 to 30 minutes for glucose de- 
terminations. Thus all glucose concentrations reported in this paper represent the average of three to five determinations at seven to ten minute intervals. Under these circumstances, it is thought proper to record glucose values to the tenth of a milligram. Our method of analysis for each sample being accurate to $1 \mathrm{mg}$. per cent, it is considered in general that arteriovenous differences of more than $2 \mathrm{mg}$. per cent are significant. This difficulty in measuring arteriovenous glucose difference when taken together with the probable error in the estimation of hepatic blood flow, as discussed above, means that the calculated net splanchnic glucose productions are only reasonably accurate estimates and that considerable variation from the normal is required before significance can be attached to such a difference.

Note was made of any anxiety or apprehension on the part of any subject during the study. That the groups of subjects were not very apprehensive is indicated by the average total oxygen consumptions (Table II) which were not in excess of 10 per cent above the normal basal, with exception of those patients with thyrotoxicosis or heart failure where basal oxygen consumption is characteristically elevated.

For the constant infusion experiments, basal blood flow and glucose studies as just described were completed first. Then 5 per cent glucose in physiological saline solution was infused intravenously, using a calibrated drip, at a rate sufficient to provide between 39 and $157 \mathrm{mg}$. of glucose per minute, and the hepatic blood flow and hepatic arteriovenous glucose differences were redetermined. As a rule, 30 minutes were allowed after beginning the infusion for equilibrium to be approached. Then three further blood samples from hepatic vein and peripheral artery were collected for bromsulphalein, oxygen, and glucose analyses.

\section{RESULTS}

It is of primary importance to establish the relationship of the calculated net splanchnic glucose production to the true hepatic production. Three patients with Laennec's cirrhosis of the liver, portal hypertension and extensive paraumbilical collateral veins have provided an opportunity to estimate arterial-portal venous and arterial-hepatic venous glucose differences (Table I). The blood flow in these veins was so rapid as to produce a loud venous hum and palpable thrill. The collaterals were proven to contain portal venous blood by the high concentration of sodium sulphathiazole which appeared there after the oral administration of that drug. The use of oral sulphathiazole together with bromsulphalein has allowed an estimation of the portal venous and hepatic arterial components of the total hepatic blood flow (20), and the simultaneous measurement of the arterial-portal collateral and arterialhepatic venous glucose differences allows correction of the net splanchnic glucose production to true hepatic glucose production, as is shown in Table I. It is seen, however, that there is an insignificant difference in glucose contents between arterial and portal venous bloods. Thus corrections in splanchnic glucose production to hepatic glucose output have been negligible and it would seem safe to assume that in the fasting state the calculated net splanchnic glucose production approximates closely the true hepatic production. This may not be true in other disease, e.g., hyperthyroidism, as it is in cirrhosis of the liver. Therefore, we shall continue to refer to our data as net splanchnic glucose production, but with a strong suspicion that we are dealing almost exclusively with hepatic glucose production.

Cherry and Crandall $(21,22)$ using the London angiostomy technique in unanesthetized fasting dogs, have found in agreement with our re-

TABLE I

Glucose differences between arterial, portal venous, and hepatic venous bloods

\begin{tabular}{|c|c|c|c|c|c|c|c|}
\hline \multirow{3}{*}{ Pt. } & \multicolumn{3}{|c|}{ Hepatic blood flow } & \multicolumn{2}{|c|}{ Blood glucose } & \multirow{2}{*}{$\begin{array}{l}\text { Net } \\
\text { splanchnic } \\
\text { glucose } \\
\text { production }\end{array}$} & \multirow{2}{*}{$\begin{array}{c}\text { Hepatic } \\
\text { glucose } \\
\text { production }\end{array}$} \\
\hline & Total & $\begin{array}{c}\text { Arterial } \\
\text { component }\end{array}$ & $\begin{array}{c}\text { Portal } \\
\text { venous } \\
\text { component }\end{array}$ & $\begin{array}{c}\text { Arterial- } \\
\text { portal } \\
\text { venous } \\
\text { diff. }\end{array}$ & $\begin{array}{l}\text { Arterial- } \\
\text { hepatic } \\
\text { venous } \\
\text { diff. }\end{array}$ & & \\
\hline & \multicolumn{3}{|c|}{ ml. per min. per sq. $M$. } & \multicolumn{2}{|c|}{ mg. per cent } & \multicolumn{2}{|c|}{ mg. per min. per sq. Ḿ. } \\
\hline $\begin{array}{l}\text { W. W. } \\
\text { E. O. No. } 1 \\
\text { E. O. No. } 2 \\
\text { C. B. }\end{array}$ & $\begin{array}{l}470 \\
570 \\
570 \\
710\end{array}$ & $\begin{array}{l}\text { Low } \\
130 \\
130 \\
530\end{array}$ & $\begin{array}{c}\text { High } \\
440 \\
440 \\
180\end{array}$ & $\begin{array}{r}0 \\
+2 \\
-1 \\
+1\end{array}$ & $\begin{array}{l}-7 \\
-9 \\
-10 \\
-11\end{array}$ & $\begin{array}{l}34 \\
50 \\
57 \\
76\end{array}$ & $\begin{array}{l}34 \\
60 \\
51 \\
77\end{array}$ \\
\hline Mean & & & & +0.5 & -9.2 & 54 & 55 \\
\hline
\end{tabular}


TABLE II

Net splanchnic glucose production in normal and diseased subjects-mean data

\begin{tabular}{|c|c|c|c|c|c|c|c|}
\hline Group & $\underset{\text { in }}{\text { group }}$ & $\begin{array}{l}\text { Oxygen } \\
\text { consumption } \\
\text { as per cent } \\
\text { of normal } \\
\text { basal }\end{array}$ & $\begin{array}{l}\text { Hepatic } \\
\text { blood } \\
\text { flow }\end{array}$ & $\begin{array}{l}\text { Splanchnic } \\
\text { oxygen } \\
\text { consumption } \\
\text { as per cent } \\
\text { of normal* }\end{array}$ & $\begin{array}{l}\text { Arterial } \\
\text { blood } \\
\text { glucose } \\
\text { conc. }\end{array}$ & $\begin{array}{l}\text { Hepatic A-V } \\
\text { glucose } \\
\text { diff. }\end{array}$ & $\begin{array}{l}\text { Net splanchnic } \\
\text { glucose } \\
\text { production }\end{array}$ \\
\hline Controls & 38 & $\begin{array}{c}\text { per cent } \\
106 \pm 2\end{array}$ & $\begin{array}{l}\text { ml. per min. } \\
\text { per sq. M. } \\
764 \pm 25\end{array}$ & $\begin{array}{l}\text { per cent } \\
95 \pm 3\end{array}$ & $\begin{array}{l}\text { mg. per cent } \\
95.9 \pm 1.6\end{array}$ & $\begin{array}{l}m g . \text { per cent } \\
8.5 \pm 0.4\end{array}$ & $\begin{array}{c}\text { mg. per min. } \\
\text { per sq. } M . \\
64.6 \pm 3.7\end{array}$ \\
\hline $\begin{array}{l}\text { Convalescent and chronic } \\
\text { infections }\end{array}$ & 8 & $106 \pm 5$ & $806 \pm 76$ & $105 \pm 6$ & $101.6 \pm 5.3$ & $\begin{array}{r}9.7 \pm 1.0 \\
p=0.2\end{array}$ & $\begin{array}{r}79.6 \pm 11.2 \\
p>0.1\end{array}$ \\
\hline $\begin{array}{l}\text { Diabetes mellitus, insulin } \\
\text { treated }\end{array}$ & 9 & $110 \pm 5$ & $784 \pm 74$ & $111 \pm 8$ & $177.9 \pm 27.9$ & $\begin{array}{r}9.6 \pm 0.9 \\
\mathrm{p}>0.2\end{array}$ & $\begin{array}{r}70.7 \pm 3.8 \\
\mathrm{p}>0.4\end{array}$ \\
\hline Laennec's cirrhosis & 18 & $108 \pm 4$ & $695 \pm 46$ & $89 \pm 5$ & $92.9 \pm 2.6$ & $\begin{array}{c}7.2 \pm 0.5 \\
p>0.05,<0.1\end{array}$ & $\begin{aligned} 49.1 & \pm 3.6 \\
p & <0.02\end{aligned}$ \\
\hline Hyperthyroidism & 10 & $148 \pm 7$ & $865 \pm 55$ & $153 \pm 7$ & $104.7 \pm 4.3$ & $\begin{array}{r}8.7 \pm 0.6 \\
p>0.5\end{array}$ & $\begin{array}{r}74.8 \pm 7.1 \\
p=0.2\end{array}$ \\
\hline Congestive heart failure & 8 & $116 \pm 7$ & $450 \pm 40$ & $114 \pm 13$ & $88.3 \pm 2.5$ & $\begin{aligned} 11.5 & \pm 1.0 \\
\mathrm{p} & <0.01\end{aligned}$ & $\begin{array}{c}50.1 \pm 4.3 \\
p>0.05,<0.1\end{array}$ \\
\hline
\end{tabular}

* The normal splanchnic oxygen consumption in a larger series of 48 controls was $34 \mathrm{ml}$. per min. per sq. M. This value is taken as 100 per cent.

sults a low glucose difference between arterial and portal venous bloods, with the hepatic venous glucose level being well in excess of the arterial. Likewise, Ravault and coworkers (8) and Sherlock and Walshe (9) found no difference in glucose between portal collateral and antecubital venous bloods in the post-absorptive state.

In Table II are given the mean data on 38 subjects who had no or insignificant disease (controls), eight patients well convalescent from acute infections or having mild chronic infectious processes, and groups of patients with diabetes mellitus, Laennec's cirrhosis, hyperthyroidism, and heart failure. In no instance in any group did the arterial glucose concentration vary by more than $3 \mathrm{mg}$. per cent during the period for which the net splanchnic glucose output was calculated. For example, the average change in arterial glucose concentration in the 38 controls was $-0.1 \mathrm{mg}$. per cent with a standard deviation of $\pm 1.2 \mathrm{mg}$. per cent. The few cases in which the arterial glucose level rose or fell by more than $3 \mathrm{mg}$. per cent are excluded from this report. These conditions would seem adequate to allow translation of splanchnic glucose outputs into peripheral glucose consumptions.

The control subjects had a mean hepatic venous glucose concentration in excess of the arterial level by $8.5 \pm 0.4 \mathrm{mg}$. per cent. ${ }^{3}$ The hepatic venous glucose concentration was higher than the arterial in every subject. The net splanchnic glucose production averaged $64.6 \pm 3.7 \mathrm{mg}$. per minute per sq. M. of body surface. The eight patients with convalescent or mild chronic infections gave values a little higher than those of the control group but not significantly so.

Nine individuals were studied with severe to moderate diabetes mellitus, all of whom had received protamine zinc insulin in adequate or inadequate amounts, the last dose having been given 24 hours before the time of study. The mean values for hepatic arteriovenous glucose difference and net splanchnic glucose production deviate insignificantly from the control figures. None of the nine patients had more than mild glycosuria at the time of study. It is not thought that this glucose loss alters the essential normality of the estimated peripheral glucose consumption in these treated diabetics.

In 11 of 18 patients with Laennec's cirrhosis of the liver, the diagnosis was proved by liver biopsy or later autopsy; in the remaining seven, the diagnosis seemed established on clinical grounds. Here the hepatic arteriovenous glucose difference was $7.2 \pm 0.5 \mathrm{mg}$. per cent, not definitely sub-

\footnotetext{
${ }^{8}$ Hereafter all \pm values are standard errors.
} 
normal as compared with the controls $(0.1>p$ $>0.05)$. The subnormal hepatic blood flows in many of the cirrhotic subjects resulted in a considerable reduction in net splanchnic glucose output to $49.1 \pm 3.6 \mathrm{mg}$. per minute per sq. M. ( $p<$ 0.02 in comparison with controls).

None of the mean values in 10 patients with moderate to severe uncomplicated thyrotoxicosis varied significantly from the controls. The net splanchnic glucose production was perhaps a little elevated.

The data on eight individuals with chronic congestive heart failure are also summarized in Table II. Their low hepatic blood flows (23) are accompanied by a significant increase in hepatic arteriovenous glucose difference to $11.5 \pm$ $1.0 \mathrm{mg}$. per cent $(\mathrm{p}<0.01)$. This change is largely but not completely compensatory for the diminished flow, the net splanchnic glucose production averaging $50.1 \pm 4.3 \mathrm{mg}$. per minute per sq. M. However, because of considerable individual variation, this decrease does not prove significant statistically in a group as small as this $(0.1>\mathrm{p}>0.05)$.

The effects of slow glucose infusion on splanchnic glucose production are given in Table III. In the first four subjects, glucose was infused at a rate moderately in excess of the immediately preceding splanchnic glucose production. In each instance the infusion of glucose at rates from 91 to $157 \mathrm{mg}$. per minute per sq. M., resulted in obliteration of the hepatic arteriovenous glucose difference. In the fifth subject, W. B., glucose was administered at a rate below his splanchnic glucose output. This smaller amount of glucose had no perceptible effect on the hepatic arteriovenous glucose difference. The last two individuals of Table III had severe diabetes mellitus under partial control with protamine zinc insulin, the "fasting" blood sugars in both being $200 \mathrm{mg}$. per cent. Again glucose intravenously in an amount moderately in excess of their control splanchnic glucose liberations resulted in disappearance of predominance of hepatic venous glucose concentration over the arterial. In one diabetic (M. P.) the usual direction of the fasting difference was reversed, indicating splanchnic (presumably hepatic) storage of glucose.

\section{DISCUSSION}

One is struck by the constancy of the glucose difference between hepatic venous and arterial blood not only in normal fasting persons but in those disease states where the hepatic blood flow is unaltered, such as controlled diabetes mellitus and hyperthyroidism. When the hepatic blood flow is decreased, as in congestive heart failure, the glucose difference is increased. But in cardiac decompensation, the increase in arteriovenous glucose difference is not adequate to compensate for the decreased blood flow, and the resulting splanchnic glucose output is moderately subnormal. The glucose output may well be less than these data indicate since the errors inherent in the bromsulphalein method of estimating hepatic blood flow are in the direction of indicating higher flows than actually exist. This is true particularly in conditions like heart failure and cirrhosis

TABLE III

Effect of slow glucose infusions on hepatic glucose production

\begin{tabular}{|c|c|c|c|c|c|c|c|}
\hline Pt. & Diagnosis & $\begin{array}{l}\text { Fasting } \\
\text { arterial } \\
\text { blood } \\
\text { glucose }\end{array}$ & $\begin{array}{l}\text { Fasting } \\
\text { hepatic } \\
\text { A-V } \\
\text { glucose } \\
\text { diff. }\end{array}$ & $\begin{array}{c}\text { Fasting } \\
\text { net } \\
\text { splanchnic } \\
\text { glucose } \\
\text { production }\end{array}$ & $\begin{array}{l}\text { Rate of } \\
\text { glucose } \\
\text { infusion }\end{array}$ & $\begin{array}{c}\text { Post- } \\
\text { infusion } \\
\text { arterial } \\
\text { blood } \\
\text { glucose }\end{array}$ & $\begin{array}{l}\text { Post- } \\
\text { infusion } \\
\text { hepatic A-V } \\
\text { glucose } \\
\text { diff. }\end{array}$ \\
\hline $\begin{array}{l}\text { I. W. } \\
\text { E. M. } \\
\text { L. B. } \\
\text { R. J. } \\
\text { W. B. } \\
\text { J. A. } \\
\text { M. P. }\end{array}$ & $\begin{array}{l}\text { Asymptomatic neuro- } \\
\text { syphilis } \\
\text { Psychoneurosis, anxiety } \\
\text { state } \\
\text { Duodenal ulcer } \\
\text { Conv. pneumonia } \\
\text { Hypertension } \\
\text { Diabetes mellitus, insulin } \\
\text { treated } \\
\text { Diabetes mellitus, insulin } \\
\text { treated }\end{array}$ & $\begin{array}{l}\text { mg. per cent } \\
105 \\
98 \\
89 \\
83 \\
109 \\
200 \\
200\end{array}$ & $\begin{array}{c}\text { mg. per cent } \\
6 \\
13 \\
10 \\
9 \\
6 \\
11 \\
6.5\end{array}$ & $\begin{array}{c}\text { mg. per min. } \\
\text { per sq. } M \text {. } \\
40 \\
113 \\
63 \\
77 \\
52 \\
80 \\
73\end{array}$ & $\begin{array}{c}\text { mg. per min. } \\
\text { per sq. } M \text {. } \\
143 \\
157 \\
91 \\
99 \\
39 \\
144 \\
144\end{array}$ & $\begin{array}{l}\text { mg. per cent } \\
152 \\
152 \\
107 \\
100 \\
114 \\
234 \\
233\end{array}$ & $\begin{array}{r}\text { mg. per cent } \\
0 \\
-2 \\
1 \\
-2 \\
6 \\
1 \\
-4\end{array}$ \\
\hline
\end{tabular}


of the liver where the ability of the liver to excrete bromsulphalein is impaired. Severe anemia, on the other hand, might be expected to show a low hepatic arteriovenous glucose difference because of the rapid hepatic blood flow. Investigation of anemia, with this point in mind, is in progress.

The assessment of anxiety during studies such as these is difficult and, accordingly, no pointed investigation of the effects of anxiety on hepatic glucose output was undertaken. Four of the control subjects summarized in Table II, and including E. M. of Table III, were noted during their study to be more apprehensive than the other subjects. This was evidenced by a startled appearance, tachycardia, mild tremor and the patients' own statement afterward confirming apprehension. It is of interest that in these four individuals, the glucose production was essentially twice normal, being 113, 135, 131, and $107 \mathrm{mg}$. per minute per sq. M., respectively. Their arterial blood sugar concentrations were within the same range as the non-anxious controls. That the extra glucose produced is metabolized in some fashion is indicated by the absence of detectable rise in the arterial blood glucose concentrations of these patients during the course of the experiment. A doubling of splanchnic glucose output with the glucose being stored in the body water into which it diffuses, rather than being metabolized, would be expected to result in a rise in blood glucose concentration of about $6 \mathrm{mg}$. per cent over a period of 20 to 30 minutes. This should be enough of a rise to measure, but as stated above, the arterial glucose level remained constant in anxiety just as in non-anxious individuals.

The net splanchnic glucose production is subnormal in Laennec's cirrhosis of the liver. The low hepatic blood flows, which many of these patients have, account for some but apparently not all of the decreased glucose outputs, even when one considers that the estimated hepatic blood flows in cirrhosis may be artefactually high, as is discussed under heart failure. The ability of the cirrhotic liver to form glucose from glycogen, as judged by the response of the blood sugar to epinephrine, is impaired (24-26). It is also possible that in cirrhosis there is impairment of gluconeogenesis. In agreement with these observations is the finding of hypoglycemia in an oc- casional instance of advanced liver disease, including cirrhosis. The finding of the subnormal peripheral glucose utilization in cirrhosis implies, in view of the normal overall metabolic rate in this disease, an increased metabolism of either fat or protein in the fasting state.

The finding of the normal net splanchnic glucose production in diabetic patients under treatment with protamine zinc insulin supports the many observations of the past that under these circumstances peripheral glucose consumption is restored essentially to normal. It must be emphasized, however, that these results have no necessary bearing on the situation which exists in the diabetic subject not under insulin treatment.

In hyperthyroidism, the net splanchnic glucose production, and presumably the peripheral glucose utilization, are little, if at all, elevated in the post-absorptive period in the face of a considerably elevated BMR $(+48 \%$ in this series $)$. Part of this discrepancy may be accounted for by the fact that the splanchnic oxygen consumption in hyperthyroidism is elevated more greatly than is the overall oxygen consumption (27). Thus the non-splanchnic metabolic rate is lower than the $\mathrm{BMR}$ and the peripheral (non-splanchnic) glucose utilization would not be expected to be elevated in proportion to the BMR.

That the metabolism of fat is increased in the post-absorptive state in hyperthyroidism is evidenced by the significant lowering of the fasting respiratory quotient, as found by Sanger and Hun (28) and Bansi and Wolter (29). The negative nitrogen balance and the tissue wasting which are observed so frequently in hyperthyroidism would support increased protein katabolism, particularly when the intake of food was inadequate to provide sufficient stores of carbohydrate and fat to meet the continued high metabolic demands of the post-absorptive period. One explanation of the relatively low splanchnic glucose production, then, might be that in the fasting state in thyrotoxicosis the proportion of carbohydrate metabolized is reduced, with fat and protein metabolisms being proportionately increased.

The liver of hyperthyroidism is not devoid of glycogen even in the fasting state (30) so that profound deficiency of glycogen cannot be invoked to explain any relative deficiency in splanchnic glucose output. Furthermore Richardson, 
Levine, and DuBois (31), by calorimetric studies in thyrotoxicosis, showed the fasting carbohydrate metabolism, which was mildly increased above normal in keeping with our determinations, to be in large part derived from preformed carbohydrate, presumably liver glycogen.

The only previous estimates in man of peripheral glucose utilization from measurement of the splanchnic glucose production are those of Bondy (5). Bondy's values are in essential agreement with ours except for several very high splanchnic glucose outputs due to hepatic arteriovenous glucose differences of as much as $38 \mathrm{mg}$. per cent. Our glucose differences, which have had a much narrower range than Bondy's, are thought to be more representative of the basal, post-absorptive state.

If for purposes of calculation it is assumed that our control subjects remained fasting for 24 hours and maintained their net splanchnic glucose productions at the rate herein determined, then the mean glucose output of $65 \mathrm{mg}$. per minute per sq. M. amounts to a total production of $162 \mathrm{gms}$. of glucose per 24 hours for a man of 1.73 sq. M. It is of interest to determine quantitatively, with the limit of our present knowledge, where this glucose is used peripherally.

Scheinberg (32) has reported the mean cerebral glucose utilization in normal young males to be $6.2 \pm 0.3 \mathrm{mg}$. per minute per $100 \mathrm{gms}$. of brain. Assuming the normal brain to weigh 1,400 gms., this cerebral glucose consumption amounts to approximately $45 \mathrm{mg}$. per minute per sq. $\mathrm{M}$. of body surface, and accounts for 112 gms., or 69 per cent of the total glucose liberated by the splanchnic area in the theoretical 24 hour period.

Subtracting the cerebral glucose utilization from the net splanchnic glucose production leaves 31 per cent $(20 \mathrm{mg}$. per minute per sq. M., or 50 gms. per 24 hours) for the rest of the body, i.e., the heart, skeletal muscles, skeleton, skin, adipose tissue, and kidneys. This offhand seems like too small an amount of glucose for all these structures. However, closer inspection of present knowledge regarding glucose differences and blood flows in these viscera brings out that the above estimate is not unreasonable.

Goodale, Olson, and Hackel (33) have recently determined, by means of catheterization of the coronary sinus, a mean glucose difference of
$10.7 \mathrm{mg}$. per cent across the coronary circulation of man during the absorptive state. In four subjects studied in the post-absorptive state, however, the glucose difference was $2 \mathrm{mg}$. per cent or less. Taken together with the low rate of coronary blood flow, $65 \mathrm{ml}$. per minute per 100 gms. of heart, reported by Bing and associates (34), the estimated cardiac glucose utilization must prove to be quite small in the fasting state.

Schwartz and Stead (35) in 15 observations on four normal subjects have been unable to demonstrate any significant difference in glucose concentration between femoral arterial and venous bloods. Somogyi (36) on the other hand has found a mean glucose difference of $4.8 \mathrm{mg}$. per cent between capillary blood and antecubital venous blood in normal fasting individuals. The range of the capillary-venous glucose difference was from 1 to $13 \mathrm{mg}$. per cent. This wide range is probably related to the great variations in peripheral blood flow, particularly through the hand, which occur with changes in such factors as room temperature and emotional status. It would seem that arteriovenous differences obtained at the base of an extremity, such as the above femoral arteriovenous differences, would be more representative of the mean glucose difference through skin, skeletal muscle and connective structures in the resting state. If Schwartz' and Stead's observations are correct, then the extremities in the resting, post-absorptive state might well be utilizing only part of the $20 \mathrm{mg}$. per minute per sq. M. of glucose left after cerebral utilization is deducted. This is not surprising in view of the practical absence of skeletal muscular work in the resting state. Increased work on the part of the skeletal muscles could be met by two mechanisms: (a) increasing the hepatic glucose production to make more glucose available for muscular use and (b) metabolizing the glucose which had been stored in the muscles as glycogen during previous postcibal periods. The evidence herein given would militate against any great transfer of glucose from the liver to skeletal muscle during the resting, post-absorptive state. Likewise the rate of any transformation of glucose to glycogen in adipose tissue would be slow.

Levitan (37) in 13 observations on six normal medical students could measure no significant glucose difference between arterial and renal venous 
bloods. The renal arteriovenous glucose difference, however, would be difficult to measure in view of the normally high rate of renal blood flow. There is evidence from animal studies (3841) that the kidney may be a site for gluconeogenesis. If this is true in normal, post-absorptive man, then the renal venous glucose level might exceed slightly the simultaneous arterial level: In any case, it would seem that the net renal glucose utilization is not large.

In summation then, the net splanchnic glucose production is distributed 69 per cent to the brain and 31 per cent to other sites (including the skeletal muscles). It is to be recalled that the glucose utilization of the various portal viscera is already accounted for in the calculations of the net splanchnic glucose production. The portal visceral utilization in the fasting state, however, is small as is indicated by the very low arterialportal collateral glucose difference.

\section{SUMMARY AND CONCLUSIONS}

1. The net splanchnic glucose production has been estimated in groups of normal and diseased humans from the product of the hepatic (splanchnic) blood flow and the hepatic arteriovenous glucose difference. The net splanchnic glucose production, at a constant arterial concentration of glucose, approximates the rate of peripheral glucose utilization.

2. In normal controls, the hepatic arteriovenous glucose difference averaged $8.5 \mathrm{mg}$. per cent and the net splanchnic glucose production $65 \mathrm{mg}$. per minute per sq. M. of body surface. Forty-five mg. of this is used by the brain, leaving $20 \mathrm{mg}$. per per minute per sq. M. for use in other locations. Argument is given that these are reasonable estimates.

3. The slow intravenous infusion of glucose at rates moderately exceeding the splanchnic glucose production obliterates the hepatic arteriovenous glucose difference. This evidence indicates the correctness of the general magnitude of the estimated net splanchnic glucose production.

4. The glucose difference between arterial and portal venous bloods is apparently negligible. The net splanchnic glucose production, then, is very close to the true hepatic glucose output.

5. In insulin treated diabetes mellitus, both the hepatic arteriovenous glucose difference and the net splanchnic glucose production are normal. The splanchnic glucose production is low in Laennec's cirrhosis of the liver. The hepatic arteriovenous glucose difference is normal in hyperthyroidism, and the splanchnic glucose output is moderately but not significantly elevated. In congestive heart failure, the hepatic arteriovenous glucose difference is high in correspondence to the decreased hepatic blood flow. The rise in glucose difference is not fully compensatory, however, resulting in a somewhat subnormal splanchnic glucose production.

\section{ACKNOWLEDGMENT}

This work was accomplished with the technical assistance of Miss Leila Holmes, Miss Mamie McLawhorn, Mrs. Juanita M. Clontz, Miss Dorothy Frederick, and Mrs. Louise Allen.

\section{BIBLIOGRAPHY}

1. Soskin, S., Essex, H. E., Herrick, J. F., and Mann, F. C., The mechanism of regulation of the blood sugar by the liver. Am. J. Physiol., 1938, 124, 558.

2. Warren, J. V., and Brannon, E. S., A method of obtaining blood samples directly from the hepatic vein in man. Proc. Soc. Exper. Biol. \& Med., 1944, 55, 144.

3. Bradley, S. E., Ingelfinger, F. J., Bradley, G. P., and Curry, J. J., The estimation of hepatic blood flow in man. J. Clin. Invest., 1945, 24, 890.

4. Myers, J. D., The hepatic blood flow and splanchnic oxygen consumption of man-their estimation from urea production or bromsulphalein excretion during catheterization of the hepatic veins. $\mathrm{J}$. Clin. Invest., 1947, 26, 1130.

5. Bondy, P. K., James, D. F., and Farrar, B. W., Studies of the role of the liver in human carbohydrate metabolism by the venous catheter technic. I. Normal subjects under fasting conditions and following the injection of glucose. J. Clin. Invest., 1949, 28, 238.

6. Bondy, P. K., Bloom, W. L., Whitner, V. S., and Farrar, B. W., Studies of the role of the liver in human carbohydrate metabolism by the venous catheter technic. II. Patients with diabetic ketosis, before and after the administration of insulin. J. Clin. Invest., 1949, 28, 1126.

7. Myers, J. D., The effects of the intravenous administration of glucose and amino acids on the hepatic blood flow and splanchnic oxygen consumption of man. Federation Proc., 1948, 7, 83.

8. Ravault, P., Girard, M., Viallier, J., and Bourdillon, Mme., Sur les valeurs chimiques comparées, du sang de la circulation veineuse générale et du sang porte chez l'homme. Compt. rend. Soc. de biol., 1941, 135, 1233. 
9. Sherlock, S., and Walshe, V., The use of a portal anastomolic vein for absorption studies in man. Clin. Sc., 1948, 6, 113.

10. Billings, F. T., and DePree, H. E., Diagnosis of portal vein obstruction; studies of intestinal absorption of glucose using abdominal collateral veins. Bull. Johns Hopkins Hosp., 1949, 85, 183.

11. Blondheim, S. H., and Kunkel, H. G., Portal blood in collateral veins of patients with cirrhosis. Acetylation by the intestine. Proc. Soc. Exper. Biol. \& Med., 1950, 73, 38.

12. Cohn, C., Levine, R., and Streicher, D., The rate of removal of intravenously injected bromsulphalein by the liver and extra hepatic tissues of the dog. Am. J. Physiol., 1947, 150, 299.

13. Cohn, C., Levine, R., and Kolinsky, M., Hepatic and peripheral removal rates, in the dog, for intravenously injected bromsulphalein. Am. J. Physiol., 1948, 155, 286.

14. Sherlock, S., Bearn, A. G., Billing, B. H., and and Paterson, J. C. S., Splanchnic blood flow in man by the bromsulfalein method: the relation of peripheral plasma bromsulfalein level to the calculated flow. J. Lab. \& Clin. Med., 1950, 35, 923.

15. Brauer, R. W., Krebs, J. S., and Pessotti, R. L., Bromsulfonphthalein as a tool for study of liver physiology. Federation Proc., 1950, 9, 259.

16. Somogyi, M., Determination of blood sugar. J. Biol. Chem., 1945, 160, 69.

17. Nelson, N., Photometric adaptation of Somogyi method for determination of glucose. J. Biol. Chem., 1944, 153, 375.

18. Van Slyke, D. D., and Neill, J. M., The determination of gases in blood and other solutions by vacuum extraction and manometric measurement. J. Biol. Chem., 1924, 61, 523.

19. Hickam, J. B., and Frayser, R., Spectrophotometric determination of blood oxygen. J. Biol. Chem., 1949, 180, 457.

20. Myers, J. D., The hepatic blood flow in Laennec's cirrhosis, with an estimate of the relative contributions from portal vein and hepatic artery. J. Clin. Invest., 1950, 29, 836.

21. Cherry, I. S., and Crandall, L. A., Jr., The response of the liver to the oral administration of glucose. Am. J. Physiol., 1937, 120, 52.

22. Cherry, I. S., and Crandall, L. A., Jr., The absence of a significant glucose-lactic acid cycle (involving the liver) in normal unanesthetized dogs. Am. J. Physiol., 1939, 125, 41.

23. Myers, J. D., and Hickam, J. B., An estimation of the hepatic blood flow and splanchnic oxygen consumption in heart failure. J. Clin. Invest., 1948, 27, 620.

24. Hildes, J. A., Sherlock, S., and Walshe, V., Liver and muscle glycogen in normal subjects, in diabetes mellitus and in acute hepatitis. Part II. The effects of intravenous adrenaline. Clin. Sc., 1949, 7, 297.
25. Kinsell, L. W., Michaels, G. D., Weiss, H. A., and Barton, H. C., Studies in hepatic glycogen storage. I. Adrenalin-induced hyperglycemia as an index of liver function. Am. J. M. Sc., 1949, 217, 554.

26. Myers, J. D., Unpublished observations.

27. Myers, J. D., Brannon, E. S., and Holland, B. C., A correlative study of the cardiac output and the hepatic circulation in hyperthyroidism. J. Clin. Invest., 1950, 29, 1069.

28. Sanger, B. J., and Hun, E. G., The glucose mobilization rate in hyperthyroidism. Arch. Int. Med., 1922, 30, 397.

29. Bansi, H. W., and Wolter, A., Das Verhalten des respiratorischen Quotienten bei der Uberfunktion der Schilddrüse. Zschr. f. klin. Med., 1937, 132, 33.

30. Piper, J., and Poulsen, E., Liver biopsy in thyrotoxicosis. Acta. med. Scandinav., 1947, 127, 439.

31. Richardson, H. B., Levine, S. Z., and DuBois, E. F., Clinical calorimetry; the storage of glycogen in exophthalmic goiter. J. Biol. Chem., 1926, 67, 737.

32. Scheinberg, P., and Stead, E. A., Jr., The cerebral blood flow in male subjects as measured by the nitrous oxide technique. Normal values for blood flow, oxygen utilization, glucose utilization and peripheral resistance, with observations on the effect of tilting and anxiety. J. Clin. Invest., 1949, 28, 1163.

33. Goodale, W. T., Olson, R. E., and Hackel, D. B., Myocardial glucose, lactate and pyruvate metabolism of normal and failing hearts studied by coronary venous catheterization in man. Federation Proc., 1950, 9, 49.

34. Bing, R. J., Hammond, M. M., Handelsman, J. C., Powers, S. R., Spencer, F. C., Eckenhoff, J. E., Goodale, W. T., Hafkenschiel, J. H., and Kety, S. S., The measurement of coronary blood flow, oxygen consumption, and efficiency of the left ventricle in man. Am. Heart J., 1949, 38, 1.

35. Schwartz, T. B., and Stead, E. A., Jr., Unpublished observations from this laboratory.

36. Somogyi, M., Studies of arteriovenous differences in blood sugar. I. Effect of alimentary hyperglycemia on rate of extrahepatic glucose assimilation. $J$. Biol. Chem., 1948, 174, 189.

37. Levitan, B. A., Unpublished observations from this laboratory.

38. Bergman, H. C., and Drury, D. R., The relationship of kidney function to the glucose utilization of the extraabdominal tissues. Am. J. Physiol., 1938, 124, 279.

39. Russell, J. A., The anterior pituitary in the carbohydrate metabolism of the eviscerated rat. Am. J. Physiol., 1942, 136, 95.

40. Reinecke, R. M., The kidney as a source of glucose in the eviscerated rat. Am. J. Physiol., 1943, 140, 276.

41. Roberts, S., and Samuels, L. T., Fasting and gluconeogenesis in the kidney of the eviscerated rat. Am. J. Physiol., 1944, 142, 240. 